\title{
The Relationship Between Dysmenorrhea And Physical Activity Of Midwifery And Psychology Students Unair
}

\author{
Feni Priana N. Chomairoh ${ }^{1}$, Euvanggelia D. Ferdinandus ${ }^{2^{*}}$, Bambang Purwanto ${ }^{1,3}$ \\ ${ }^{1,2}$ Department of Midwifery Education, Faculty of Medicine, Airlangga University 60132, Surabaya, East Java, Indonesia \\ ${ }^{3}$ Department of Medical Physiology, Faculty of Medicine, Airlangga University 60132, Surabaya, East Java, Indonesia
}

Corresponding Author: euvanggelia.dwilda@fk.unair.ac.id

\begin{abstract}
Background: Dysmenorrhea is pain felt during menstruation. Dysmenorrhea is one of the causes of chronic pelvic pain. As many as $45-95 \%$ of women of productive age experience dysmenorrhea. The incidence rate of primary dysmenorrhea is $72.89 \%$ and secondary dysmenorrhea is $27.11 \%$. A preliminary study of 10 students of Midwifery and Psychology Unair, obtained the results of all students experiencing dysmenorrhea where 7 out of 10 students tend to do light physical activity when experiencing dysmenorrhea. This study aims to find out if there is a link between dysmenorrhoea and physical activity. Methods: The study was conducted from March to November 2021 in the Midwifery and Psychology Study Program of Airlangga University, with 36 respondents taken by random sampling method and used a questionnaire as the instrument. Data analysis using the chi-square test. Results: The study showed that of the 36 respondents mostly felt mild dysmenorrhea, namely as many as 19 students $(52.8 \%), 3$ students $(8.3 \%)$ felt moderate dysmenorrhea, 4 students $(11.1 \%)$ felt heavy dysmenorrhea, and 10 other students $(27.8 \%)$ did not feel pain or dysmenorrhea at the time of menstruation were 24 students (66.7\%) underwent light physical activity, 10 students $(27.8 \%)$ underwent moderate physical activity, and 2 other students $(5.5 \%)$ undergo strenuous physical activity. Chi-Square statistical test results with $\alpha$ 0.05 showed that the $\mathrm{p}$-value of $0.248>\alpha 0.05$ so that $\mathrm{H}_{0}$ was rejected. The analysis concluded that there was no relationship between dysmenorrhea and physical activity in midwifery and psychology students. Conclusion: This study concludes that there is no relationship between dysmenorrhea and the physical activity of midwifery and psychology students.
\end{abstract}

Keywords: students, dysmenorrhea, physical activity

\section{Introduction}

Dysmenorrhea is the pain during menstruation. Dysmenorrhea is one of the causes of chronic pelvic pain. According to Beddu (2015), dysmenorrhea is the pain in the lower part of the stomach which radiates legs or back, occurring during or before menstruation. The cause of dysmenorrhea is an imbalance of progesterone hormone in the blood that causes pain (Istiqomah, 2009).

Mulastin (2010) states that $64.25 \%$ of women of productive age in Indonesia experience dysmenorrhea/ menstrual pain. According to Tomas and Magos (2009), the prevalence of female adolescents in Indonesia experiencing dysmenorrhea is about $43 \%$ - 93\%. In her study, Iswari (2014) proved that 140 students $(88.6 \%)$ experienced moderate dysmenorrhea, and 18 students $(11.4 \%)$ experienced severe dysmenorrhea. A total of 108 students $(68.4 \%)$ felt that their activities were disturbed due to 
dysmenorrhea, 34 students $(21.5 \%)$ were severely disturbed, and 16 students $(10.1 \%)$ were not disturbed. It might conclude that dysmenorrhea affects young women's physical activity

To relieve the symptoms when experiencing menstrual pain, use analgesic drugs, non-steroid antiinflammatory drugs (NSAIDs), and hormone therapy (combination pills) as pharmacological therapy. As for non-pharmacological therapies, such as warm water compresses, visualization therapy, massage, exercise, and enough sleep. A preliminary study of 10 female students showed that 7 out of 10 female students tended to do light activities, such as sitting and resting. When experiencing dysmenorrhea, they did not do moderate activities, such as exercising. Based on this, it allows for a relationship between dysmenorrhea and physical activity. Therefore, researchers want to find out more about the relationship between dysmenorrhea and physical activity of students of the Midwifery and Psychology study program Unair.

\section{Method}

This type of research is quantitative research, observational analytics using cross-sectional studies. The population of this study is a student of the class of 2018 Midwifery and Psychology Study Program of Airlangga University with total respondents of 36 . This study uses a random sampling technique. Data collection is conducted in March - November 2021 start with the determination of research samples. The instrument used in the study was a questionnaire. Data processing has done by editing, coding, data entry, and tabulating. Data has been collected and processed is then analyzed using the help of the SPSS computer program version 25. Data analysis consists of univariate and bivariate analysis with a chisquare test.

\section{Result}

Table 1. Characteristics and General Data Respondents at Midwifery and Psychology Unair Students

\begin{tabular}{|c|c|c|c|}
\hline Characteristics & & Frequency (n) & Percentage (\%) \\
\hline \multirow{4}{*}{ Age } & 19 & 1 & 2,7 \\
\hline & 20 & 6 & 16,7 \\
\hline & 21 & 23 & 63,9 \\
\hline & 22 & 6 & 16,7 \\
\hline \multirow{5}{*}{ Age of Menarche (years) } & 11 & 7 & 19,4 \\
\hline & 12 & 15 & 41,7 \\
\hline & 13 & 7 & 19,4 \\
\hline & 14 & 3 & 8,4 \\
\hline & 15 & 4 & 11,1 \\
\hline \multirow{4}{*}{ BMI (Body Massa Index) } & Less $(\leq 18,4)$ & 6 & 16,7 \\
\hline & Normal $(18,5-25,0)$ & 20 & 55,5 \\
\hline & Fat $(25,1-27,0)$ & 3 & 8,4 \\
\hline & Obesity $(>27,0)$ & 7 & 19,4 \\
\hline
\end{tabular}

Table 2. Distribution of Menstrual Duration of Midwifery and Psychology Unair Students

$\begin{array}{lll}\text { Mentrual Duration (days) } & \text { Frequency (n) } & \text { Percentage }(\%)\end{array}$




\begin{tabular}{cccc}
\hline$<8$ & 29 & 80,6 & 19,4 \\
\hline $8-10$ & 7 & 19,4 \\
\hline
\end{tabular}

Table 3. Distribution of Dysmenorrhea Events in Midwifery and Psychology Students Unair

\begin{tabular}{ccc}
\hline Dysmenorrhea Events & Frequency $(\mathbf{n})$ & Percentage $(\%)$ \\
\hline No Dysmenorrhea & 10 & 27,8 \\
Dysmenorrhea & 26 & 72,2 \\
\hline
\end{tabular}

Table 4. Frequency Distribution of Pain Intensity Dismenorea Student Midwifery and Psychology Unair

\begin{tabular}{ccc}
\hline Intensity of Pain & Frequency (n) & Percentage (\%) \\
\hline No Pain (0) & 10 & 27,8 \\
Lighweight (1-3) & 19 & 52,8 \\
Medium (4-6) & 3 & 8,3 \\
Weight (7-10) & 4 & 11,1 \\
\hline
\end{tabular}

Table 5. Distribution of Frequency of Physical Activity of Midwifery and Psychology Students Unair

\begin{tabular}{ccc}
\hline Physical Activity & Frequency (n) & Percentage (\%) \\
\hline Lightweight $(\leq 600)$ & 24 & 66,7 \\
\hline Medium $(>600)$ & 10 & 27,8 \\
\hline Weight $(>3000)$ & 2 & 5,5 \\
\hline
\end{tabular}

Table 8. Cross-Tabulation of Dismenorea Relationship with Physical Activity of Midwifery and Psychology Students Unair

\begin{tabular}{|c|c|c|c|c|c|c|c|c|c|c|c|}
\hline \multirow{3}{*}{$\begin{array}{l}\text { Physical } \\
\text { Activity }\end{array}$} & \multicolumn{10}{|c|}{ Intensity of Pain } & \multirow{3}{*}{$P$ value } \\
\hline & \multicolumn{2}{|c|}{ No Pain } & \multicolumn{2}{|c|}{ Lightweigth } & \multicolumn{2}{|c|}{ Medium } & \multicolumn{2}{|c|}{ Weight } & \multirow{2}{*}{$\mathrm{N}$} & \multirow{2}{*}{$\%$} & \\
\hline & $\mathrm{N}$ & $\%$ & $\mathrm{~N}$ & $\%$ & $\mathrm{~N}$ & $\%$ & $\mathrm{~N}$ & $\%$ & & & \\
\hline Lightweigth & 6 & 16,7 & 15 & 41,7 & 1 & 2,8 & 2 & 5,6 & 24 & 66,7 & \\
\hline Medium & 4 & 11,1 & 2 & 5,6 & 2 & 5,6 & 2 & 5,6 & 10 & 27,8 & 0,248 \\
\hline Weight & 0 & 0 & 2 & 5,6 & 0 & 0 & 0 & 0 & 2 & 5,6 & \\
\hline
\end{tabular}

The table above obtains that of the 10 students who did not experience dysmenorrhea, 6 students $(16.7 \%)$ do light physical activity, 4 students $(11.1 \%)$ do moderate physical activity, and no students do strenuous activities. In students who experienced dysmenorrhea with light intensity, there were 15 female students $(41.7 \%)$ undergoing light physical activity, 2 students $(5.6 \%)$ undergoing moderate activities, and 2 other students $(5.6 \%)$ undergoing strenuous activity. While in 4 female students who experienced severe dysmenorrhea, 2 students $(5.6 \%)$ underwent light physical activity, 2 others $(2.6 \%)$ underwent moderate physical activity, and no students underwent strenuous activity.

After processing data using SPSS version 25 and calculated by the Chi-Square test with an $\alpha 0.05$, it was obtained that the p-value of $0.248>\alpha 0.05$ so that $\mathrm{H}_{0}$ was rejected. The analysis showed that there was no association between dysmenorrhea and physical activity of Midwifery and Psychology students Unair. 


\section{Discussion}

\subsection{Characteristics of Respondents}

Based on the study, 26 (72.2\%) of the 36 students who were respondents had dysmenorrhea. The age of the respondents was calculated from the date of birth until the research was conducted. In this study, all respondents were between 19 and 22 years. Peak dysmenorrhea occurs between ages 15 to 25 years (Andira, 2013). Reeder and Koniak (2011) said that at the age of 25, women will experience increased pain. When the age reaches 30 to 35 years, the pain will reduce. As you get older, the cervix will widen. As a result, the secretion of prostaglandin hormones will decrease, and dysmenorrhea will decrease as the function of the uterine nerves decreases (Novia, 2006).

The results showed most female menarche by the age of 12 years. According to Cunningham (2005), the average age of menarche is $12-13$ years but does not rule out the possibility of early menarche at the age of 10 years or late menarche that can occur until the age of 16 years. This result is in coherence with the research conducted by Aditiara (2018) on nursing students of Muhammadiyah University of Surakarta. The result shows a significant relationship between menarche age and dysmenorrhea incidence. According to Widjanarko (2006), the readiness of reproductive organs maturity influenced the relationship between menarche age and dysmenorrhea. Dewi (2012) says that the organs that experience maturations are the ovaries, hypothalamic axial, and pituitary. Where RHaffected pituitaries will secrete FSH and LH further respond to the production of gonadotropins, it affects endometrial growth. While the absence of fertilization will cause regression of the corpus luteum, decreased progesterone, and increased prostaglandins that stretch myometrium so that there is a decrease in blood flow to the uterus and resulting in pain (Sherwood, 2011).

This study found that the BMI of respondents is mostly normal, which is as many as 20 female students (55.5\%). IMT has a relationship with dysmenorrhea (Nohara, 2011). According to Fritz (in Yunita, 2016), prostaglandin is one of the factors that cause dysmenorrhea, prostaglandins are derivative of arachidonic-acid metabolism produced through the esterification process of fatty acids and cholesterol.

The majority of female students menstruate with a duration of $<8$ days, which is as many as 29 female students (80.6\%), while seven female students (19.4\%) menstruate for 8-10 days. This result indicates that the woman who has a longer menstrual duration will experience more pain caused by uterine contractions in the secretion phase. According to Shanon (in Sinaga, 2016) uterine contractions will cause blood flow to the uterus to stop temporarily, resulting in dysmenorrhea.

\subsection{Relationship Between Dysmenorrhea and Physical Activity}

The results showed that most of Unair's Midwifery and Psychology students who suffered from dysmenorrhea during menstruation felt a mild intensity of pain, namely as many as 19 female students $(52.8 \%), 3$ female students (8.3\%) felt pain with moderate intensity, and 4 female students $(11.1 \%)$ felt pain with weight intensity. Another 10 female students $(27.8 \%)$ did not feel pain or dysmenorrhea during menstruation. Several factors that affect physical activity include age, sex, diet, rest patterns, and diseases/abnormalities in the body. One of the disorders that can affect physical 
activity is dysmenorrhea. The research obtained results through the filling of the IPAQ questionnaire by respondents. There are different METs-average results of Midwifery students with Psychology due to daily differences midwifery students have done hybrid lectures that cause physical activity of midwifery students greater than psychology students who still conduct an online class. The results showed that the average METs in midwifery students amounted to 854 while psychology students amounted to 512,4. Overall results showed that most of the 24 students (66.7\%) do light physical activity, 10 students $(27.8 \%)$ do moderate physical activity, and 2 other students (5.5\%) do strenuous physical activity.

Physical activity accords to WHO is any body movement produced by skeletal muscles that require energy expenditure. Physical activity refers to all movement include during leisure time, for transportation to get to and from a place or work. This activity includes activities carried out at school, at work, activities in the family/household, activities during the trip, and other activities carried out to fill daily leisure time (Kemenkes RI, 2018).

The correlation test using SPSS version 25 and calculated by the Chi-Square test with an $\alpha 0.05$ obtains that the p-value of $0.248>\alpha 0.05$ so that H0 rejected. From this analysis, researchers conclude that there is no relationship between dysmenorrhea and physical activity in female students of Midwifery and Psychology Unair.

The results of this study are in line with the results of research conducted by Annisa (2017) on the relationship of physical activity with the incidence of primary dysmenorrhea in santri in Pondok pesantren $\mathrm{X}$ in Bogor regency. A statistical test using the Fisher exact test showed no relationship between physical activity and the occurrence of primary dysmenorrhea with a value of $p=0.372$. The number of respondents who experienced dysmenorrhea with light physical activity was 50 people (58.1\%), respondents with moderate physical activity as many as 20 people (23.3\%), and respondents with heavy physical activity as many as 6 people $(7 \%)$.

This result is not in coherence with the research conducted by Fitria (2021) on the relationship of physical activity with the incidence of dysmenorrhea in SMK Kesehatan Pelita Bogor Regency. Fitria's research shows that the majority of students, 169 of 215 respondents $(74,4 \%)$, do light physical activities. Statistical tests showed that the p result is $0.006(<0.05)$, and there was a relationship between physical activity and dysmenorrhea in students of Bogor Pelita Health Vocational School.

Several things such as age, sex, diet, rest patterns, and diseases/abnormalities in the body influence physical activities. One of the disorders that can affect physical activity is dysmenorrhea. Diseases/abnormalities in the body can affect the capacity of the heart and lungs, posture, sugar levels, hemoglobin, or blood cells and muscle cells. Menstrual pain usually occurs due to excessive release of certain prostaglandins, prostaglandins - F2 $\alpha$, from cells of the endometrium cells of the uterus. Prostaglandin - F2 $\alpha$ is a powerful stimulant of myometrium smooth muscle contraction and constriction of uterine blood vessels. This situation can cause more severe uterine hypoxia that causes severe pain (Corwin, 2009). Some ways have been done to reduce dysmenorrhea that infers 
along with physical activity, including drugs, relaxation, hypnotherapy, and various treatment alternatives such as warm water compresses, aromatherapy, visualization therapy, regular exercise, massage (acupressure), and others (Turana, 2004). Dysmenorrhea is not the main factor that affects physical activity. Dysmenorrhea can be prevented or reduced in some easy ways to do. However, Dysmenorrhea is still concerning as many women, especially women who experience dysmenorrhea, suffer from it.

This study concludes that dysmenorrhea does not affect the physical activity of sufferers much. The other factor playing a considerable role in physical activity is age. The older the people, the more reduction in functional capacity throughout the body will be. Diet also affects physical activity. If the amount of food entering the body is more, the body will tire more quickly. As a result, there will be a lack of motivation to do activities.

\section{Conclusion}

1. Most Unair's Midwifery And Psychology students who are disposed to be respondents experience mild dysmenorrhea during menstruation.

2. Most of Unair's Midwifery And Psychology students undergo light physical activity while experiencing dysmenorrhea.

3. There was no association between dysmenorrhea and the physical activity of midwifery and psychology students in this study. However, dysmenorrhea is still concerning. Dysmenorrhea, especially severe dysmenorrhea, can disturb some women.

\section{Suggestion}

1. For respondents

Respondents are advised not to take drugs when experiencing mild dysmenorrhea that does not interfere with activity. However, it is advisable to do the treatment both pharmacologically and nonpharmacologically for respondents whose physical activity is disturbed due to dysmenorrhea, especially in people with severe dysmenorrhea.

2. For institutions

It is necessary to do counseling and counseling to students about reproductive health, especially dysmenorrhea so that students are able to overcome dysmenorrhea that occurs during menstruation.

3. For the Next Researcher

More research is needed on other factors that can affect physical activity such as age, diet, rest patterns, and others.

\section{Acknowledgements}

The author would like to express her deepest gratitude to the head of Midwifery and Psychology Program of Airlangga University who have given permission to conduct research in that place, the supervisor who has guided during the research process and preparation of this manuscript and the researcher does not forget to thank her parents and friends. Researchers who have provided support for researchers to complete this research well.

\section{References}


Alimuddin, A. 2017. Hubungan Dismenorea dengan Aktivitas Belajar Mahasiswa Prodi DIV Jurusan Kebidanan Poltekkes Kemenkes Kendari. Skripsi. Repository Poltekkes Kemenkes Kendari.

Ammar, Ulya R. 2016. Faktor Risiko Dismenore Primer Pada Wanita Usia Subur Di Kelurahan Ploso Kecamatan Tambaksari Surabaya. FKM Universitas Airlangga.

Ariani, Malisa. 2018. Hubungan Usia Menarche Dengan Kejadian Dismenore Primerpada Remaja Putri Kelas Viii Di Smp Negeri 9 Banjarmasin. Jurnal Kampus STIKes YPIB Majalengka. 7(14).

Elvira Aditiara, B., \& Wahyuni, S. 2018. Hubungan Antara Usia Menarche Dengan Dysmenorrhea Primer. Doctoral dissertation, Universitas Muhammadiyah Surakarta.

Irianti, Berliana. 2018. Faktor-Faktor Yang Mempengaruhi Kejadian Dismenore Pada Remaja. Menara Ilmu Akademi Kebidanan Internasional Pekanbaru. Vol XII.

Kementrian Kesehatan Republik Indonesia. 2018. Aktivitas Fisik. Direktorat Jenderal Pencegahan Dan Pengendalian Penyakit.

Kusmiyati, K., Merta, I. W., \& Bahri, S. 2016. Studi Pengetahuan Tentang Menstruasi Dengan Upaya Penanganan Dismenore Pada Mahasiswa Pendidikan Biologi. Jurnal Pijar Mipa, 11(1).

Sukini T., Tri W. L., Mundarti. Acupressure and Decrease Pain Menstruation (Dysmenorrhea Primary. Acupressure and Decrease Pain Menstruation, 199 - 204.

Tristiana, A. 2019. Hubungan Aktivitas Fisik Dengan Kejadian Dismenore Primer Pada Santri Di Pondok Pesantren X Di Kabupaten Bogor (Bachelor's thesis, FKIK UIN Jakarta).

Wahyu, A. 2019. Hubungan Dismenorea Primer Dengan Aktivitas Belajar Pada Siswi SMAN 8 Surabaya. Skripsi. Repository Universitas Airlangga.

Wibawati, F. H. 2021. Hubungan Aktivitas Fisik Dengan Kejadian Dismenore Pada Siswi Di Smk Kesehatan Pelita Kabupaten Bogor. Jurnal Ilmiah Wijaya, 13(2).

World Health Organization. 2020. WHO Guidelines on Physical activity and Sedentary Behaviour. 